\title{
Concepts and Criteria for the Classification of Small and Medium-sized Business in Russia
}

\author{
Submitted 01/02/19, 1st revision 18/03/19, 2nd rervision 20/04/19, accepted 05/06/19
}

\section{T.A. Skvortsova ${ }^{1}$, A.A. Nikitina ${ }^{2}$, T.A. Pasikova ${ }^{3}$, A.V. Tagaev ${ }^{4}$}

\begin{abstract}
:
Purpose: The purpose of the article is to study the concepts and criteria for classifying businesses to the category of Small and Medium-sized business according to the legislation of the Russian Federation. In the course of the study, the authors analyzed the criteria by which the subjects are identified as Small and Medium-sized enterprises and, accordingly, are entitled to receive state support.

Design/Methodology/Approach: The authors' analysis is based on the literature review and statistical data analysis regarding the concept of entrepreurship and its legal background.

Findings: The authors presented analytical data on business entities, citizens engaged in entrepreneurial activity, state support of entrepreneurial activity and introduced a conceptual classification benchmark.

Practical implications: Authors' findings could be applied in improving the legal and economic entrepreneurial frameworks of Russia.

Originality/Value: The contribution of the article is the authors' approach in classifying SMEs (Small and Medium-sized entities) and their state support as well as recommendations regarding the entrepreneurial activity and its development.
\end{abstract}

Keywords: Entrepreneurship, commercial organizations, citizens-entrepreneurs, Small and Medium-sized business, government support for Small and Medium-sized business.

JEL Codes: K19, O17.

Paper Type: Research article in Special Issue dedicated to Russian Economy.

Section 8: Business and Economic Issues.

\footnotetext{
${ }^{1}$ Ph.D., in Law, Associate Professor, Rostov State University of Economics, Rostov-on-Don, tas242@yandex.ru

${ }^{2}$ Ph.D., in Law, Associate Professor, Rostov State University of Economics, Rostov-on-Don, oooytsrostov@rambler.ru

${ }^{3}$ Ph.D., in Law, Associate Professor, Rostov State University of Economics, Rostov-on-Don, tatyana-plotko@yandex.ru

${ }^{4}$ Ph.D., in Economics, Associate Professor, URIU RANEPA, Rostov-on-Don, tagaevav@uriu.ranepa.ru
} 


\section{Introduction}

The market mechanism of management as a fundamental importance of the driver of economic dynamics reveals a complex phenomenon - the system of entrepreneurship. Entrepreneurship is a specific transformative purposeful activity with following features:

First, independence and riskiness: the subject realizes his/her own talents, abilities, initiatives in the conditions of the market managerial mechanism determined by a set of multidirectional trends and, for this reason, which is difficult to predict.

Second, the target orientation: the subject final goal is making a profit and obtaining socially significant effects.

Third, it is determined by the use of available specific «mechanisms»: creation and supply of a product (goods, services) to the market, effective management of the property complex (as well as a set of intangible assets).

It can be said that the fundamental purpose of entrepreneurial behaviour (and, therefore, management, modeling and management of strategic risks) is to maximize profits, consistent maintenance of (relative) financial stability of an business subject through rational financial and economic, production and technical policy. Economic literature highlights the following positive aspects of entrepreneurial activity:

First, entrepreneurship is a mechanism to meet the effective demand of the population.

Secondly, entrepreneurship is a factor of macroeconomic dynamics in a competitive market, where resources are limited, needs are unlimited, the environment is tough, aggressive and competitive.

Third, entrepreneurship is always based on the desire of the subjects to maximize profits and socially significant benefits. The «synergetic sum» of such trends is an unambiguous driver for the development of the national economy as a whole.

Fourth, entrepreneurship is the most «mobile» phenomenon, capable of a very rapid internal structural transformation: changes in market requirements, customer needs, resource base conditions. These aspects cause the most rapid and adequate response from the subjects of entrepreneurial initiative.

The business subjects can carry out activities in the form of legal entities commercial organizations and individual entrepreneurs. Table 1 represents the statistics of commercial organizations of various organizational and legal forms existing in Russia now. 
Table 1. Business organizations in Russia on December 5, 2018.

\begin{tabular}{|l|r|}
\hline \multicolumn{1}{|c|}{ Type } & \multicolumn{1}{|c|}{ Number } \\
\hline Business organizations & 3548841 \\
\hline Companies with additional responsibility & 5 \\
\hline Joint stock companies & 76276 \\
\hline Non-public joint-stock companies & 62029 \\
\hline Public joint-stock companies & 13169 \\
\hline Production cooperatives & 12140 \\
\hline Unitary enterprises & 17150 \\
\hline Other commercial organizations & 11067 \\
\hline General partnerships & 177 \\
\hline Limited liability companies & 3431702 \\
\hline Trust partnerships & 324 \\
\hline
\end{tabular}

Article 23 of the Civil Code of the Russian Federation also allows for entrepreneurial activity without the formation of a legal entity from the moment of state registration as an individual entrepreneur, as well as, in cases provided for by law - without such registration. Table 2 represents statistics of citizens engaged in entrepreneurial activity without forming a legal entity.

Table 2. Citizens of the Russian Federation engaged in business on December 5, 2018

\begin{tabular}{|l|r|}
\hline \multicolumn{1}{|c|}{ Type } & \multicolumn{1}{|c|}{ Number } \\
\hline Citizens of the Russian Federation & 3936034 \\
\hline Individual entrepreneurs & 3786738 \\
\hline Registered before 01.01.2004 & 443236 \\
\hline Registered after 01.01.2004 & 3343502 \\
\hline Peasant (farmer) farms & 149296 \\
\hline $\begin{array}{l}\text { Registered before the entry into force the part one of the Civil Code of the } \\
\text { Russian Federation }\end{array}$ & 8031 \\
\hline $\begin{array}{l}\text { The heads of which are registered as individual entrepreneurs before } \\
\text { 01.01.2004 }\end{array}$ & 16555 \\
\hline Registered after 01.01.2004 & 124710 \\
\hline
\end{tabular}


Especially among persons engaged in entrepreneurial activity, the subjects of small and medium-sized business are distinguished. The need for small and medium business is due not only to the development of market relations, but also the implementation of reforms in the country's economy, that is economically feasible, since the emergence of a large number of new companies entails the emergence of new jobs, in addition, increasing the budget income of all levels, due to taxes and fees. The development of the Small and Medium-sized business sector (SMEs) is a basic and objectively necessary element of the socio-economic system of the country. The experience of market-developed countries convinces of the objective need for the development in any national economy of an effective Small and Medium-sized business sector (Epifanova et al., 2015).

The experience of market-developed countries convinces the objective need for the development of an effective Small and Medium-sized business sector in any national economy (Epifanova et al., 2015). In modern Russia, the position of small and medium-sized business, providing significant GDP growth and covering a number of important sectors for the normal development of the society (mainly related to food production, provision of all kinds of services to the population, transport and other areas that serve daily human life), is certainly important for any economy of the world.

At the same time, despite their importance, these subjects are not financially stabile, unlike the subject of large business. The share of small and medium-sized business in the gross product is unacceptably small and is $20 \%$, while European indicators are close to $75 \%$ (Ruchkina, 2017). The low legal and economic level of knowledge of the population is one the the negative factors hindering the development of small and medium-sized business. In order to develop small and medium-sized business in Russia it is necessary to focus on:

- training of personnel ready for independent professional activity in the sphere of small and medium business;

- formation of entrepreneurial thinking and entrepreneurial competencies;

- creating a positive image of entrepreneurs and cultivating the spirit of entrepreneurship among young people (Ruchkina, 2017).

In addition, it is necessary to create special legal conditions for the development of small and medium-sized business, to determine the mechanisms of their state support. In this context, criteria for assigning the subjects to the small and medium enterprises become important.

\section{Criteria for the Assignment of Business in SMEs}

According to item 1 of Article 3 of the Federal law on July 24, 2007 № 209-FL «About the development of small and medium-sized business in the Russian Federation» «the economic subjects (legal entities and individual entrepreneurs) 
referred according to the conditions established by this Federal law to the small enterprises, including microenterprises, and medium enterprises belong to the subjects of small and medium-sized business» (the Federal law of July 24, 2007) № 209-FL «On the development of small and medium-sized business in the Russian Federation»).

At the same time, in accordance with part 1 of Article 4 of the Federal law «On the development of small and medium-sized business in the Russian Federation», these subjects can have different organizational and legal forms: these can be economic societies, economic partnerships, economic cooperatives, consumer cooperatives, peasant (farmer) farms and individual entrepreneurs. It should be admitted that the list of organizational and legal forms of business in which the subjects of small and medium-sized business can be created is closed. Thus, in the edition of the Federal law «On the development of small and medium-sized business in the Russian Federation» which was in force until 03.08.2018, this list did not include business partnerships.

In this regard, there was said in the letter of the Federal tax service on 20.04.2018 № MMV-17-14/97, explaining the issue of referring economic partnership to the subjects of small and medium-sized business: «the possibility of referring to the subjects of small and medium-sized business, including trust partnerships (limited partnerships), the Federal law on July 24, 2007 №. 209-FL «On the development of small and medium-sized business in the Russian Federation» is not provided, and therefore the legal basis for entering into the Unified register of small and mediumsized business of information about the relevant legal entities are not available» (Letter of the Federal tax service on 20.04.2018 № MMV-17-14/97 Question: On referring economic partnership to small and medium-sized business). Later a business partnership reasonably was included into the above list and now the partnership may be included into the register of subjects of small and medium-sized business. The Federal law «On the development of small and medium-sized business in the Russian Federation» defines three groups of conditions (restrictions) for obtaining the status of a subject of small and medium-sized business:

1) At least one of the following requirements should be fulfilled for business entities, business companies and business partnerships:

a) it is necessary to say about a so-called «criterion of independence» (the Russian Federation, subjects of the Russian Federation, municipalities, public or religious organizations (associations), charitable and other funds (except investment funds) own totally not more than $25 \%$ of the authorized (share) capital, and foreign legal entities and/or legal entities that are not the subjects of small and medium-sized business own totally not more than $49 \%$ of the authorized (share) capital);

b) shares of joint-stock company trading in the organized securities market are shares of high-tech (innovative) sector of economy;

c) activity of economic societies, economic partnerships consists of practical application (introduction) of intellectual activity results (programs for electronic 
computers, databases, inventions, useful models, industrial samples, selection achievements, topologies of integrated circuits, secrets of production (know-how), exclusive rights to which belong to founders (participants) of such economic societies, economic partnerships - budgetary, autonomous scientific institutions or budgetary, autonomous organizations of higher education;

g) economic societies, economic partnerships obtained the status of the participant of the project in accordance with the Federal law on 28 September 2010 № 244-FL «About the innovative centre «SKOLKOVO»;

e) founders (participants) of economic societies, economic partnerships are the legal entities included into the list of the legal entities providing the state support to innovative activity on condition of compliance to one of criteria, established by the legislation;

2) The average number of employees for the previous calendar year should not exceed the following limits of the average number of employees for each category of small and medium-sized business:

a) from 101 to 250 persons for medium-sized enterprises;

b) up to 100 people for small business; microenterprises (which stand out among small businesses) up to 15 people;

3) Income received from entrepreneurial activity for the previous calendar year should not exceed the limits established by the Government of the Russian Federation for each category of small and medium-sized business.

Fulfilling this obligation, the Government of the Russian Federation approved the limit values of income: microenterprises is 120 million rubles; small enterprises is 800 million rubles; medium-sized enterprises is 2 billion rubles (Government Decree of the Russian Federation № 265 on 04.04.2016 «On the limit values of income received from entrepreneurial activity for each category of small and medium-sized business»).

According to A.P. Tenishev, the head of the Anti-cartel Department of the Federal Antimonopoly Service of the Russian Federation, such revenue indicators do not quite meet the realities of the domestic economy. After all, if we take for example the budgets of regional cities, they will be comparable to the income of some of our «small» and «medium» enterprises. For example, the budget of the city of Alexandrov in Vladimir Region is slightly more than 220 million rubles with a population of 59 thousand people, and the budget of the city of Kstov in Nizhny Novgorod Region is 467 million rubles with a population of 67 thousand people (the Cartels: the results of the FAS of Russia in 2017 and plans for 2018).

We wholly agree with this point of view. In this regard, we propose to establish the previously existing criteria for maximum income in order to classify as small and medium-sized enterprises: microenterprises is 60 million rubles; small enterprises is 400 million rubles; medium-sized enterprises is 1000 million rubles. 
Information on legal entities and individual entrepreneurs that meet the conditions of classification to the subjects of small and medium-sized business are included into in the unified register of the subjects of small and medium-sized business. The maintenance of a uniform register of the subjects of small and medium-sized business is carried out by Federal Tax Service. As follows from the materials of judicial practice the availability of information in the tax administration's register is sufficient to confirm the status of a small business subject (Decision of the Moscow Arbitration court from 22.11.2017 on business no. A40-131607/17-21-698).

\section{State Support of SMEs}

Russian legislation provides many types of support and benefits for of the subjects of Small and Medium-sized business. To obtain such support, a subject of business has the right to apply in the prescribed form (Order № 113 of the Ministry of Economic Development of the Russian Federation of 10.03.2016 «On approval of the application form for compliance of a newly created legal entity and a newly registered individual entrepreneur with the conditions of assignment to the subjects of small and medium-sized business established by the Federal law of 24 July 2007) № 209-FL «On the development of Small and Medium-sized business in the Russian Federation»).

First, privileges are established in the sphere of taxation, provision of statistical reports, accounting and order of cash operations. Thus, the subjects of small business have the right to prepare reports both on conventional and simplified forms. The difference between the simplified forms and the usual ones is that all the reporting indicators are reflected in them in aggregate, by groups of articles (Dmitrieva, 2017).

Second, it is the creation of a sales market by creating an infrastructure to support of the subjects of small and medium-sized business in accordance with article 15 of the Federal law «On the development of small and medium-sized business in the Russian Federation» in procurement for state and municipal needs.

Third, it is financial support for Small and Medium-sized business. In accordance with article 17 of the Federal law «On the development of small and medium-sized business in the Russian Federation», the subjects of small and medium-sized business are provided with subsidies, budget investments, as well as state and municipal guarantees for their obligations from the expense of the budgets of the subjects of the Russian Federation and local budgets.

Also, the measures of state support include property support, information support, consulting support, personnel training and retraining. It should be noted that Russian legislation in 2016 established special conditions for the appointment of administrative penalties for individual business. Thus, taking into account the current version of the Code of Administrative Offences of the Russian Federation, 
special conditions for the application of administrative sanctions are established for the subjects of small and medium-sized business, for example, in the form of replacing an administrative fine with a warning if the offense is committed for the first time (Peresedov, 2018).

Thus, the subjects of Small and Medium-sized business have various preferences provided by the state. The status of a small business entity gives some advantages to a person carrying out business activity. In this regard, there arises the question about the possibility of classifying as small business citizens carrying out certain types of business activities established by law, but without state registration according to article 23 of the Civil Code of the Russian Federation.

Since the list of the subjects that belong to the category of small and medium-sized business is closed, it can be concluded that citizens who carry out business activity without state registration as individual entrepreneurs in cases provided by law can not be classified as the subject of small business, and, accordingly, these subjects can not use the preferences established by the state for small business. This does not seem to be logical, since such citizens relating to the number of employees and income from the sale of products may be classified as the subjects of small business. We believe that it is necessary to extend the preferential regime of entrepreneurial activity provided for small business to citizens engaged in certain types of business activities without state registration. This will encourage such persons to legalize their business activities. In order to do this, it is necessary to create a legal mechanism for the inclusion of these persons into the register of the subjects of small and medium-sized business.

\section{Conclusion}

Thus, the legislator especially determines the legal status of Small and Mediumsized business: there are defined criteria for classifying economic entities as the subjects of Small or Medium-sized business; there are established mechanisms of state support for such entities. At the same time, in our opinion, the limit values of income received from entrepreneurial activity for each category of Small and Medium-sized business established by the Government of the Russian Federation are overstated. Therefore, we propose to move to the limit values that were established before: for micro-enterprises is 60 million rubles; for small enterprises is 400 million rubles; for medium-sized enterprises is 1 billion rubles.

In addition, we believe that it is necessary to extend the preferential regime of entrepreneurial activity provided for small business to citizens engaged in certain types of business activity without state registration. This will encourage such persons to legalize their business activity. In order to do this, it is necessary to create a legal mechanism for the inclusion of these persons into the register of the subjects of small and medium-sized business. 


\section{References:}

Albekov, A., Vovchenko, N., Medvedkina, Y., Medvedkin, T. 2017. Green Economy and Economic Growth: Trends, Challenges and Opportunities for the EU. International Journal of Economics \& Business Administration, 1(5), 49-62.

Bulletin of State Registration. 2018. Available online: www.vestnik-gosreg.ru/

Dmitrieva, O.V. 2017. Application of Simplified Methods of Accounting and Preparation of Simplified Accounting (financial) Statements by economic entities in 2017. Accounting in budget and non-profit organizations, 22, 2-9.

Epifanova, T.V, Romanenko, N.G, Mosienko, T.A, Skvortsova, T.A, Kupchinskiy, A. 2015. Modernization of Institutional Environment of Entrepreneurship in Russia for Development of Innovation Initiative in Small Business Structures. European Research Studies Journal, 3(18), 137-148.

Peresedov, A.M. 2018. The Establishment of a Differentiated Size of Administrative Responsibility for Different Categories of Controlled entities in order to ensure and protect the interests of small and medium-sized businesses. Business Security, 1, 3034.

Ruchkina, G.F. 2017. Financial Support as a Key Component in the Development of Small and Medium-sized Businesses. Banking Law, 5, 7-12.

Shatkovskaya, T.V., Epifanova, T.V. 2016. Correlation of Private and Public Legal Interests as Theoretical and Scientific and Practical Problems of Modern Law. Journal of Advanced Research in Law and Economics, 7(3), 625-643.

Shatkovskaya, T.V., Solonchenko, A.A., Emirsultanov, Ya.A., Naumenko, Yu.A. 2017. Leading Governments Legal Initiatives of Innovative Development in the Sphere of Commercialization of Intellectual Products. European Research Studies Journal, 3B(20), 432-442.

Tenishev, A.P. 2018. Cartels: The results of the FAS Russia in 2017 and plans for 2018. An Internet-interview with, the Head of the Cartel Control Department of the Federal Antimonopoly Service of the Russian Federation), Legal Reference System "ConsultantPlus". 